\title{
Valkuaistäydennys lypsylehmän ummessaoloajan ruokinnassa
}

\author{
Tuomo Kokkonen \\ Helsingin yliopisto, Kotieläintieteen laitos, PL 28, 00014 Helsingin yliopisto, \\ tuomo.kokkonen@helsinki.fi
}

Lypsylehmä ei pysty ummessaollessaan varastoimaan valkuaista yhtä suuressa määrin kuin rasvaa. Lähinnä lihaksista ja nahasta mobilisoituva valkuainen voi kuitenkin edistää maitotuotosta ensimmäisinä poikimisen jälkeisinä viikkoina, kun lehmä ei kykene tyydyttämään energian ja valkuaisen tarvetta rehun syönnillä. Mobilisoituvaa valkuaista voidaan käyttää maitovalkuaisen synteesiin, glukoosin muodostamiseen tai laajentuvan ruoansulatuskanavan rakennusaineeksi.

Valkuaislisän antamisen ennen poikimista on esitetty lisäävän maidon valkuaispitoisuutta ja/tai valkuaistuotosta poikimisen jälkeen. Valkuaislisän on myös arvioitu lisäävän lehmän mobilisoitavissa olevia valkuaisvaroja tai estävän valkuaisen mobilisaation ennen poikimista, jos dieetin valkuaispitoisuus on niukka.

Tässä kirjallisuuskatsauksessa neljäntoista vertaisarvioiduissa tieteellisissä artikkeleissa julkaistun tutkimuksen tuloksia on käytetty muodostamaan tietokanta, jota käyttäen poikimista edeltävän valkuaislisän vaikutuksia on arvioitu meta-analyysin avulla. Artikkeleista kaksi perustuu kotimaisiin ja loput ulkomaisiin tutkimuksiin. Tutkimuksissa on käytetty sekä yhden että useamman kerran poikineita lehmiä. Koeruokintojen kesto ennen poikimista oli 21-42 päivää.

Poikimista edeltävän ruokinnan valkuaispitoisuuden vaikutusta poikimisen jälkeiseen maitotuotokseen ja rehun syöntiin testattiin SAS-ohjelmiston MIXED-proseduurilla. Tilastollisessa mallissa tutkimusta käytettiin satunnaistekijänä. Mikäli samassa tutkimuksessa oli faktorina valkuaispitoisuuden lisäksi energiataso tai poikimakerta, näiden faktorien tasot tulkittiin tässä analyysissa erillisiksi vertailuiksi.

Poikimista edeltävän ruokinnan valkuaispitoisuudella ei ollut tilastollisesti merkitsevää $(P>0,15)$ yhteyttä maito- ja valkuaistuotokseen tai maidon valkuaispitoisuuteen. Lisäksi mallien selitysasteet olivat alhaisia. Koska myöskään toisen asteen vaikutus ei ollut tilastollisesti merkitsevä, analyysitulokset eivät tue teoriaa, että niukasti valkuaista (100-120 g RV/kg ka) sisältävän, poikimista edeltävän ruokinnan täydentäminen valkuaislisällä lisäisi maito- tai valkuaistuotosta.

Valkuaisvarastojen kertymistä ja mobilisaatiota on useimmissa tutkimuksissa seurattu puutteellisin menetelmin, vain joissakin tutkimuksissa on käytetty typpitasekokeita tai määritetty veren tai virtsan 3-metyylihistidiinipitoisuuksia.

Tämän tutkimuksen perusteella poikimista edeltävän ruokinnan valkuaispitoisuus ei ole merkittävä yksittäinen tuotoskauden alun maito- tai valkuaistuotoksen selittäjä. On kuitenkin mahdollista, että suurimmassa osassa tutkimuksia on käytetty niin runsasta dieetin valkuaispitoisuutta (170-190 g $\mathrm{RV} / \mathrm{kg} \mathrm{ka}$ ) poikimisen jälkeen, että tämä on kompensoinut poikimista edeltävän ruokinnan mahdolliset puutteet. Lisäksi eri kokeissa on käytetty useita erilaisia valkuaislähteitä, mikä selittää vaihtelevia tuotosvasteita.

Asiasanat: lypsylehmä, tunnutus, valkuaistarve 


\section{Johdanto}

Lypsylehmä ei ole rasvavarastoihin verrattavia valkuaisvarastoja, joita se voisi käyttää poikimisen jälkeisen energia- ja ravintoainevajeen täyttämiseen. Lehmä voi kuitenkin mobilisoida aminohappoja kudoksistaan. Tärkein aminohappojen lähde ovat luurankolihakset, mutta jonkin verran aminohappoja mobilisoidaan myös nahasta sekä kohdusta sen pienentyessä tiineyden jälkeen.

Mobilisoitavan valkuaisen osuus voi maksimissaan olla jopa 25-27 \% ruumiin kokonaisvalkuaisesta (Botts ym. 1979). Mitatut mobilisoidun valkuaisen kokonaismäärät ovat vaihdelleet välillä 0-21 kg (Chilliard ym. 1991, Gibb ym. 1992, Andrew ym. 1994, Komaragiri ja Erdman 1997, Tamminga ym. 1997, Phillips ym. 2003). Tamminga ym. (1997) laskivat viiden kokeen perusteella, että valkuaisen mobilisaatio saavutti huippunsa $(4,6 \mathrm{~kg})$ neljännellä tuotosviikolla ja että ensimmäisten neljän tuotosviikon aikana mobilisoitu valkuainen riitti 3,9 kg:n päivittäiseen maitotuotokseen.

Van Saun ym. (1993) ja Moorby ym. (1996) esittivät, että valkuaislisän antaminen ennen poikimista lisäisi lehmän mobilisoitavissa olevia valkuaisvaroja tai estäisi valkuaisen mobilisaation ennen poikimista, jos dieetin valkuaispitoisuus on niukka. Heidän tutkimuksissaan valkuaislisä ennen poikimista lisäsi maidon valkuaispitoisuutta ja/tai valkuaistuotosta poikimisen jälkeen. Myöhemmissä tutkimuksissa suotuisaa vaikutusta valkuaistuotokseen tai -pitoisuuteen ei kuitenkaan ole usein havaittu.

Tämän tutkimuksen tavoitteena oli koota yhteen poikimista edeltävää valkuaisruokintaa koskevat tutkimukset ja tutkia meta-analyysin keinoin, onko ennen poikimista annetulla valkuaislisällä vaikutusta lehmien maitotuotokseen tai maidon koostumukseen poikimisen jälkeen. Hypoteesina oli, että poikimista edeltävän ruokinnan valkuaispitoisuuden nostaminen lisää maitovalkuaisen tuotosta tai maidon valkuaispitoisuutta.

\section{Aineisto ja menetelmät}

Tutkimuksessa käytettyä tietokantaa muodostettaessa käytettiin 14 vertaisarvioiduissa tieteellisissä artikkeleissa julkaistun tutkimuksen tuloksia (Taulukko 1). Artikkeleista kaksi perustui kotimaisiin ja loput ulkomaisiin tutkimuksiin. Viidessä tutkimuksessa pääasiallinen karkearehu oli nurmisäilörehu, viidessä maissisäilörehu ja lopuissa jokin muu (vehnän olki, vehnäsäilörehu, nurmiheinä, sinimailasheinä tai -säilörehu). Tutkimuksissa oli käytetty sekä yhden että useamman kerran poikineita lehmiä. Koeruokintojen kesto ennen poikimista oli 21-42 päivää.

Poikimista edeltävän ruokinnan valkuaispitoisuuden vaikutusta poikimisen jälkeiseen maitotuotokseen, maidon koostumukseen ja rehun syöntiin testattiin SAS-ohjelmiston MIXEDproseduurilla käyttäen 1. ja 2. asteen regressiomalleja. Tilastollisissa malleissa tutkimusta käytettiin satunnaistekijänä (St-Pierre 2001). Mikäli samassa tutkimuksessa oli faktorina valkuaispitoisuuden lisäksi energiataso tai poikimakerta, näiden faktorien tasot tulkittiin tässä analyysissa erillisiksi vertailuiksi. Lineaarisiin malleihin sisällytettiin leikkauspiste ja kulmakerroin sekä kiinteänä että satunnaistekijänä. Mallin random-lauseessa käytettiin rakenteetonta kovarianssimatriisia (UN). Esitetyt regressiokäyrät on piirretty mallien ennustamien arvojen perusteella.

\section{Tulokset ja tulosten tarkastelu}

Poikimista edeltävän ruokinnan valkuaispitoisuudella ei ollut tilastollisesti merkitsevää $(P>0,15)$ lineaarista vaikutusta maitotuotokseen, maitovalkuaisen tuotokseen, maidon valkuaispitoisuuteen sekä kuiva-aineen kokonaissyöntiin. Myöskään toisen asteen vaikutukset eivät olleet tilastollisesti merkitseviä (Kuvat 1 ja 2). Tämä viittaa siihen, että niukastikaan (alle $120 \mathrm{~g} \mathrm{RV} / \mathrm{kg}$ ka) valkuaista sisältävän poikimista edeltävän ruokinnan valkuaistäydennyksellä ei ole sellaista vaikutusta, joka näkyisi maitotuotoksessa tai maidon koostumuksessa (Kuva 3).

Useat tekijät vaikeuttavat poikimista edeltävän ruokinnan vaikutusten tarkastelua ja voivat estää tilastollisesti merkitsevän yhteyden löytämisen. Eri tutkimuksissa on käytetty vaihtelevasti erilaisia lisävalkuaisen lähteitä poikimista edeltävää ruokintaa täydennettäessä. Osassa tutkimuksista lisävalkuainen on ollut runsaasti ohitusvalkuaista sisältävää. Dieetin valkuaispitoisuuden ja valkuaisen laadun lisäksi ohutsuolesta imeytyvän valkuaisen määrään vaikuttaa myös pötsissä fermentoituvan orgaanisen aineen määrä. Dieetin raakavalkuaispitoisuuden käyttäminen valkuaisen saantia selittävänä muuttujana kuvaa siis heikosti lehmien aminohapposaannissa tapahtuneita muutoksia (Bell ym. 2000). 
Suurimmassa osassa kokeita poikimisen jälkeisen ruokinnan valkuaispitoisuus on ollut tuotosvaiheen mukaisesti melko runsas. Vain kahdessa tutkimuksessa (Chew ym. 1984 (152 g RV/kg ka) ja Tesfa ym. 1999 (140 g RV/kg ka)) tuotoskauden ruokinnan valkuaispitoisuus oli alle $160 \mathrm{~g} \mathrm{RV} / \mathrm{kg} \mathrm{ka}$. Todennäköisesti tuotoskauden runsas valkuaisruokinta, kun säilörehuruokinta on vapaata, peittää mahdolliset pienet puutteet ummessaoloajan valkuaisruokinnassa. Ensi kertaa poikivat lehmät hyötyvät kuitenkin ehkä poikimista edeltävästä valkuaislisästä enemmän kuin vanhemmat lehmät (Tesfa ym. 1999, Santos ym. 2001, Robinson ym. 2001, Robinson ym. 2004).

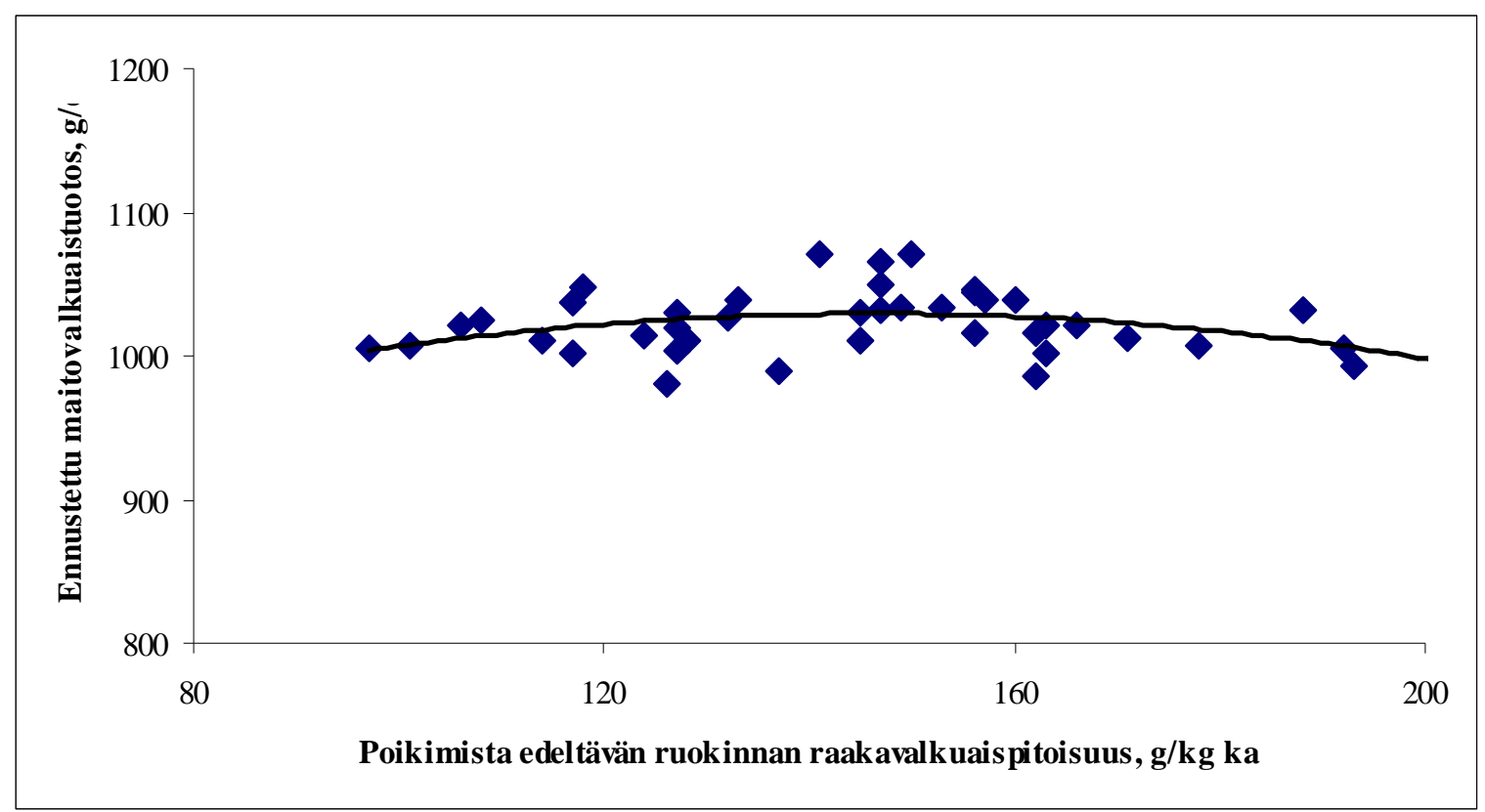

Kuva 1. Poikimista edeltävän ruokinnan vaikutus maitovalkuaisen tuotokseen $\left(\mathrm{y}=-0,01 \mathrm{x} \mathrm{RVEP}^{2}+3,13 \mathrm{x}\right.$ $\mathrm{RVEP}+800,5, \mathrm{R}^{2}=0,17, \mathrm{~N}=42$ )

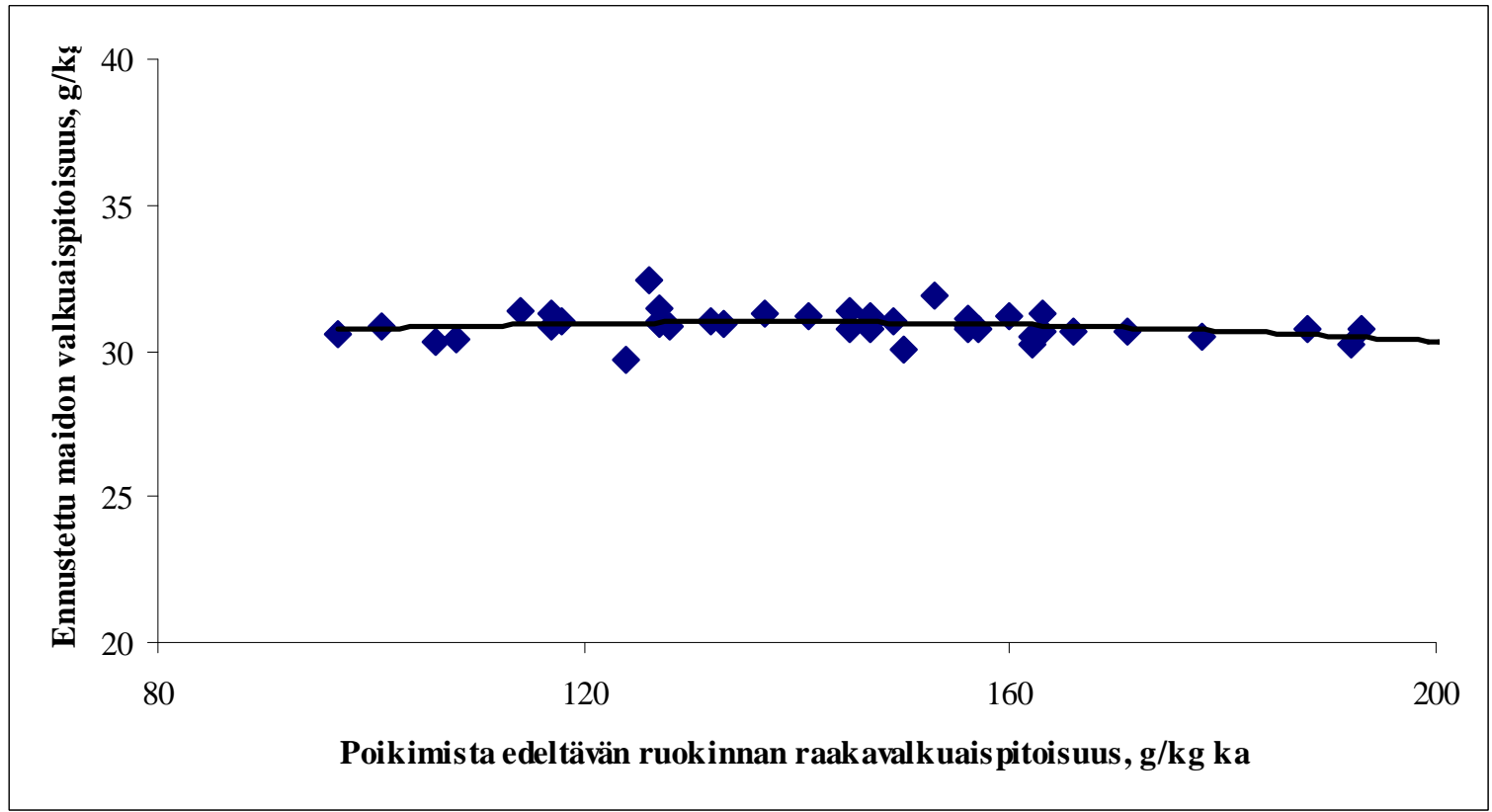

Kuva 2. Poikimista edeltävän ruokinnan vaikutus maidon valkuaispitoisuuteen $\left(y=-0,0002 x \operatorname{RVEP}^{2}+0,047 \mathrm{x}\right.$ $\mathrm{RVEP}+27,8, \mathrm{R}^{2}=0,12, \mathrm{~N}=42$ ) 


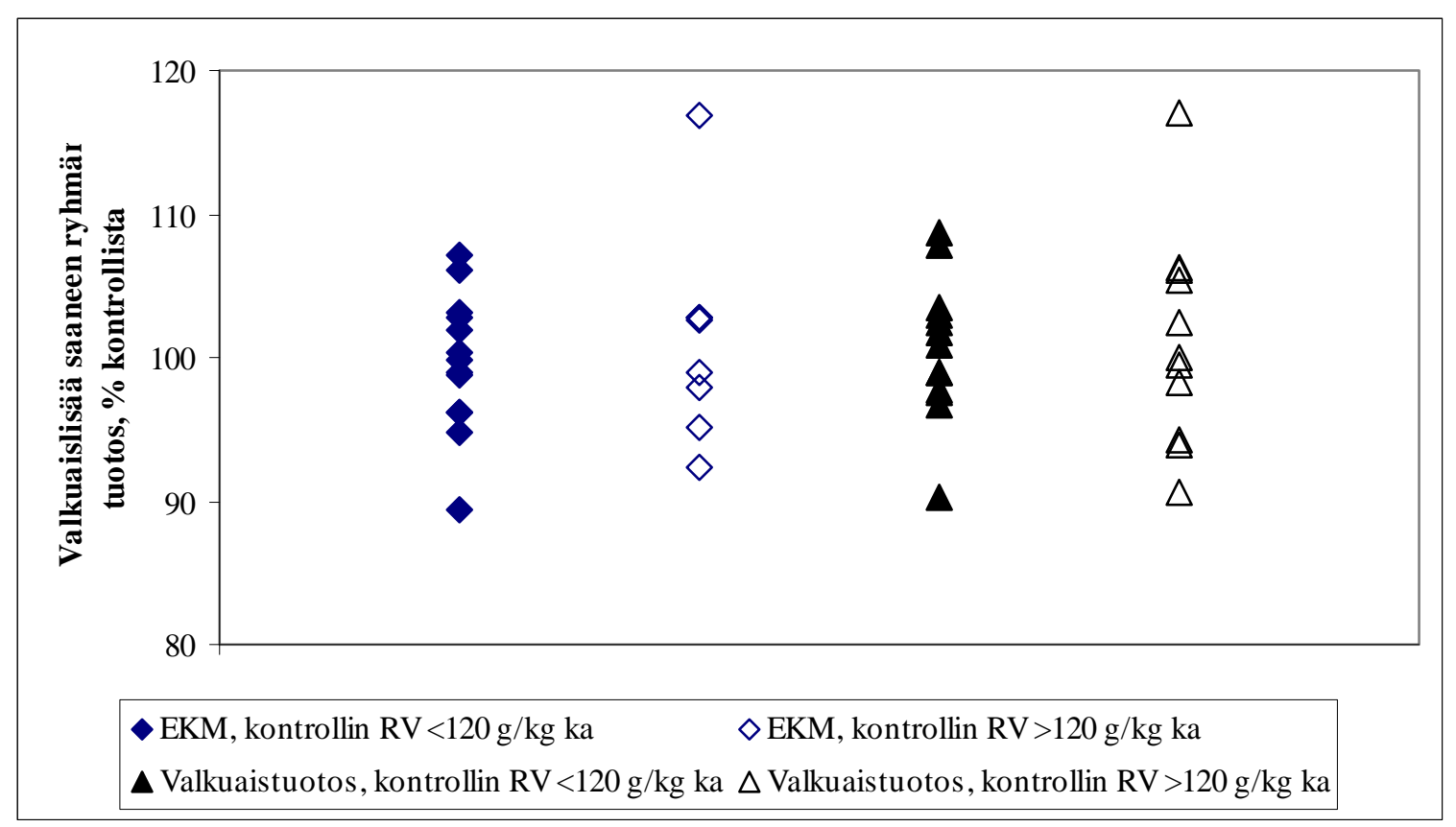

Kuva 3. Poikimista edeltävän ruokinnan vaikutus EKM- ja valkuaistuotokseen, kun kontrollitaso oli alle tai yli $120 \mathrm{~g} \mathrm{RV} / \mathrm{kg} \mathrm{ka}$

Poikimista edeltävän ruokinnan valkuaispitoisuuden lisäämistä on perusteltu poikimisen jälkeen mobilisoitavissa olevien valkuaisvarastojen lisäämisellä. Van Saun ym. (1993) ja Moorby ym. (1996) esittivät, että hyvälaatuisen lisävalkuaisen antaminen estää valkuaisvarastojen ennenaikaisen käytön tiineyden viimeisten viikkojen aikana. Valkuaisvarastojen kertymistä ja niiden mobilisaatiota maitotuotoksen tueksi on kuitenkin tutkittu vain muutamissa kokeissa ja niissäkin puutteellisin menetelmin.

Moorbyn ym. (1997) typpitasekokeissa nurmisäilörehuruokinnan täydentäminen maissigluteenijauholla ennen poikimista näytti lisäävän valkuaisen mobilisaatiota tuotoskauden alussa pelkkään nurmisäilörehuruokintaan tai nurmisäilörehu/olkiruokintaan verrattuna. Tasekokeiden väli oli kuitenkin liian pitkä valkuaismobilisaation todenmukaiseen kuvaamiseen. Myöhemmät tutkimukset eivät vahvistaneet ensimmäisen tutkimuksen havaintoa (Moorby ym. 2000, 2002). Virtsan 3metyylihistidiinin ja kreatiniinin suhteen muutosten perusteella Vandehaar ym. (1999) eivät havainneet poikimista edeltävän valkuaislisän vaikuttavan valkuaisen mobilisaatioon välillä 2 viikkoa ennen poikimista ja 2 viikkoa poikimisen jälkeen. Veren 3-metyylihistidiinin ja kreatiniinin suhteen perusteella Phillips ym. (2003) totesivat, että ennen poikimista valkuaislisää saaneiden lehmien valkuaismobilisaatio oli vähäisempää viikko poikimisen jälkeen. Poikimista edeltävän valkuaisruokinnan vaikutuksista lehmän valkuaisvarastoihin tai niiden mobilisaatioon tarvittaisiin lisätietoa nimenomaan tuotoskauden ensimmäisten viikkojen ajalta. Kudoksista mobilisoituvat aminohapot ovat tärkeä maksan glukoosin tuotannon raaka-aine tuotoskauden alussa.

\section{Johtopäätökset}

Poikimista edeltävän ruokinnan raakavalkuaispitoisuuden lisäämisellä ei ole selkeää, yhtenäistä vaikutusta lypsylehmien maitotuotokseen, maitovalkuaisen tuotokseen tai maidon valkuaispitoisuuteen. Käytännössä hyvälaatuisen säilörehun vapaa saanti sekä runsas väkirehuruokinta poikimisen jälkeen peittävät poikimista edeltävän valkuaisruokinnan puutteet. Lisätietoa tarvittaisiin siitä, mikä on poikimista edeltävän valkuaisruokinnan vaikutus aminohappojen mobilisaation kudoksista ja niiden käyttöön glukoosin tuotantoon maksassa ensimmäisinä poikimisen jälkeisinä viikkoina. 


\section{Kirjallisuus}

Andrew, S.M., Waldo, D.R. \& Erdman, R.A. 1994. Direct analysis of body composition of dairy cows at three physiological stages. J. Dairy Sci. 77: 3022-3033.

Bell, A.W., Burhans, W.S. \& Overton, T.R. 2000. Protein nutrition in late pregnancy, maternal protein reserves and lactation performance in dairy cows. Proc. Nutr. Soc. 59: 119-126.

Botts, R.L., Hemken, R.W. \& Bull, L.S. 1979. Protein reserves in the lactating dairy cow. J. Dairy Sci. 62: 433-440.

Chew, B.P., Murdock, F.R., Riley, R.E. \& Hillers, J.K. 1984. Influence of prepartum dietary crude protein on growth hormone, insulin, reproduction, and lactation of dairy cows. J. Dairy Sci. 67: 270-275.

Chilliard, Y., Cissé, M., Lefaivre, R. \& Rémond, B. 1991. Body composition of dairy cows according to lactation stage, somatotropin treatment, and concentrate supplementation. J. Dairy Sci. 74: 3103-3116.

Dewhurst, R.J., Moorby, J.M., Dhanoa, M.S., Evans, R.T. \& Fisher, W.J. 2000. Effects of altering energy and protein supply to dairy cows during the dry period. 1. Intake, body condition, and milk production. J. Dairy Sci. 83: 1782-1794.

Gibb, M.J., Ivings, W.E., Dhanoa, M.S. \& Sutton, J.D. 1992. Changes in body components of autumn-calving Holstein-Friesian cows over the first 29 weeks of lactation. Anim. Prod. 55: 339-360.

Greenfield, R.B., Cecava, M.J., Johnson, T.R. \& Donkin, S.S. 2000. Impact of dietary protein amount and rumen undegradability on intake, peripartum liver triglycerides, plasma metabolites, and milk production in transition cows. J. Dairy Sci. 83: 703-710.

Hartwell, J. R., Cecava, M. J. \& Donkin, S. S. 2000. Impact of dietary rumen undegradable protein and rumen-protected choline on intake, peripartum liver triacylglyceride, plasma metabolites and milk production in transition dairy cows. J. Dairy Sci. 2000 83: 2907-2917.

Huyler, M.T., Kincaid, R.L. \& Dostal, D.F. 1999. Metabolic and yield responses of multiparous Holstein cows to prepartum rumen-undegradable protein. J. Dairy Sci. 82: 527-536.

Komaragiri, M.V.S. \& Erdman, R.A. 1997. Factors affecting body tissue mobilization in early lactation dairy cows. 1. Effect of dietary protein on mobilization of body fat and protein. J. Dairy Sci. 80: 929-937.

Moorby, J.M., Dewhurst, R.J. \& Marsden, S. 1996. Effects of increasing digestible undegraded protein supply to dairy cows in late gestation on the yield and composition of milk during the subsequent lactation. Anim. Sci. 63: 201-213.

Moorby, J.M., Miles, S., Evans, R.T., Fisher, W.J. \& Davies, D.W.R. 1997. Changes of nitrogen balance of dairy cows during the dry period and early lactation following different dry period diets. In: Proceedings of the British Society of Animal Science 1997, Annual Meeting. p. 94.

Moorby, J.M., Dewhurst, R.J., Tweed, J.K.S., Dhanoa, M.S. \& Beck, N.F.G. 2000. Effects of altering the energy and protein supply to dairy cows during the dry period. 2. Metabolic and hormonal responses. J. Dairy Sci. 83: 1795-1805.

Moorby, J.M., Dewhurst, R.J., Evans, R.T. \& Fisher, W.J. 2002. Effects of varying the energy and protein supply to dry cows on high-forage systems. Livest. Prod. Sci. 76: 125-136.

Park, A.F., Shirley, J.E., Titgemeyer, E.C., Meyer, M.J., VanBaale, M.J. \& VandeHaar, M.J. 2002. Effect of protein level in prepartum diets on metabolism and performance of dairy cows. J. Dairy Sci. 85: 1815-1828.

Phillips, G.J., Citron, T.L., Sage, J.S., Cummins, K.A., Cecava, M.J. \& McNamara, J.P. 2003. Adaptations in body muscle and fat in transition dairy cattle fed differing amounts of protein and methionine hydroxy analog. J. Dairy Sci. 86: 3634-3647.

Putnam, D.E. \& Varga, G.A. 1998. Protein density and its influence on metabolite concentration and nitrogen retention by Holstein cows in late gestation. J. Dairy Sci. 81: 1608-1618.

Putnam, D.E., Varga, G.A. \& Dann, H.M. 1999. Metabolic and production responses to dietary protein and exogenous somatotropin in late gestation dairy cows. J. Dairy Sci. 82: 982-995.

Robinson, P.H., Moorby, J.M., Arana, M., Hinders, R., Graham, T., Castelanelli, L. \& Barney, N. 2001. Influence of close-up dry period protein supplementation on productive and reproductive performance of Holstein cows in their subsequent lactation. J. Dairy Sci. 84: 2273-2283.

Robinson, P.H., Moorby, J.M., Arana, M. \& Graham, T. 2004. Effect of feeding a high- or low-rumen escape protein supplement to dry Holstein cows and heifers within 3 weeks of calving on their productive and reproductive performance in the subsequent lactation. Anim. Feed Sci. Tech. 114: 43-57.

Santos, J.E.P., DePeters, E.J., Jardon, P.W. \& Huber, J.T. 2001. Effect of prepartum dietary protein level on performance of primigravid and multiparous Holstein dairy cows. J. Dairy Sci. 84: 213-224.

St-Pierre, N.R. 2001. Invited review: Integrating quantitative findings from multiple studies using mixed model methodology. J. Dairy Sci. 84: 741-755.

Tamminga, S., Luteijn, P.A. \& Meijer, R.G.M. 1997. Changes in composition and energy content of liveweight loss in dairy cows with time after parturition. Livest. Prod. Sci. 52: 31-38. 
Tesfa, A.T., Tuori, M., Syrjälä-Qvist. L., Pösö, R., Saloniemi, H., Heinonen, K., Kivilahti, K., Saukko, T. \& Lindberg, L-A. 1999. The influence of dry period feeding on liver fat and postpartum performance of dairy cows. Anim. Feed Sci. Tech. 76: 275-295.

Tesfa, A.T., Kokkonen, T., Tuori, M., Saukko, T., Lindberg, L-A., Pösö, R., Saloniemi, H. \& SyrjäläQvist, L. 2001. The effect of prepartum protein feeding on postpartum lactation performance of Ayrshire heifers and cows. J. Anim. Feed Sci. 10: 73-89.

VandeHaar, M.J., Yousif, G., Sharma, B.K., Herdt, T.H., Emery, R.S., Allen, M.S. \& Liesman, J.S. 1999. Effect of energy and protein density of prepartum diets on fat and protein metabolism of dairy cattle in the periparturient period. J. Dairy Sci. 82: 1282-1295.

Van Saun, R.J., Idleman, S.C. \& Sniffen, C.J. 1993. Effect of undegradable protein amount fed prepartum on postpartum production in first lactation Holstein cows. J. Dairy Sci. 76: $236-244$. 
Taulukko 1. Kooste kokeista, joissa on tutkittu poikimista edeltävän valkuaislisän tuotosvaikutuksia

\begin{tabular}{|c|c|c|c|c|c|c|c|c|c|}
\hline Koe & Vertailu & Lähde & $\mathrm{N}$ & $\begin{array}{l}\text { RV ennen poiki- } \\
\text { mista, g/kg ka }\end{array}$ & $\begin{array}{l}\text { Ka-syönti ennen } \\
\text { poikimista, } \mathrm{kg} / \mathrm{d}\end{array}$ & $\begin{array}{l}\text { Ka-syönti poikimisen } \\
\text { jälkeen, kg/d }\end{array}$ & $\begin{array}{l}\text { Maitotuotos, } \\
\mathrm{kg} / \mathrm{d}^{1}\end{array}$ & $\begin{array}{l}\text { Valkuaistuotos, } \\
\mathrm{g} / \mathrm{d}^{1}\end{array}$ & Karkearehu \\
\hline \multicolumn{10}{|c|}{ Ad libitum ruokinta ennen poikimista: } \\
\hline 1 & 1 & Dewhurst ym. 2000 & 3 & $101-171$ & $7.8-9.4$ & $17.3-17.6$ & $26.1+0.6$ & $796+28$ & Nurmisr \\
\hline 2 & 2 & Greenfield ym. 2000 & 2 & $118-163$ & $11.6-11.7$ & $21.8-19.8$ & $40.8-3.0$ & $1240-120$ & Maissisr, heinä \\
\hline 3 & 3 & Hartwell ym. 2000 & 2 & $141-162$ & $12.6-12.2$ & $22.7-20.8$ & $39.1-2.5$ & $1180-110$ & Maissisr, heinä \\
\hline 4 & 4 & Huyler ym. 1999 & 3 & $117-206$ & $10.5-10.8$ & $19.4-21.5$ & $36.6+3.0$ & $1140+100$ & Olki, heinä \\
\hline 5 & 5 & Moorby ym. 2002 & 2 & $108-145$ & $7.6-8.6$ & $15.8-15.6$ & $24.0-1.2$ & $731-16$ & Nurmisr, olki \\
\hline 5 & 6 & Moorby ym. 2002 & 2 & $163-192$ & $10.3-11.0$ & $15.5-15.8$ & $24.5+0.3$ & $769-13$ & Nurmisr \\
\hline 7 & 8 & Phillips ym. 2003 & 2 & $114-156$ & $12.7-13.3$ & $25.1-25.8$ & $40.6+1.7$ & $1299+38$ & Heinä \\
\hline 8 & 9 & Santos ym. 2001 & 2 & $127-147$ & & & $30.4+2.0$ & $929+58$ & Vehnäsr, heinä \\
\hline 8 & 10 & Santos ym. 2001 & 2 & $127-147$ & & & $42.8+0.2$ & $1293-7$ & Vehnäsr, heinä \\
\hline 9 & 11 & Van Saun ym. 1993 & 2 & $124-153$ & $8.4-8.1$ & & $25.1-0.5$ & $740+40$ & Nurmisr \\
\hline 10 & 12 & VandeHaar ym. 1999 & 2 & $142-162$ & $11.6-11.7$ & $20.8-20.5$ & $36.7-0.3$ & & $\begin{array}{l}\text { Sinimailassr, } \\
\text { Maissisr }\end{array}$ \\
\hline \multicolumn{10}{|c|}{ Rajoitettu ruokinta ennen poikimista: } \\
\hline 11 & 13 & Putnam \& Varga 1998 & 3 & $106-145$ & $11.0-11.3$ & $18.7-17.4$ & $40.8-0.6$ & $1208-13$ & Maissisr, heinä \\
\hline 13 & 15 & Tesfa ym. 1999 & 2 & $126-150$ & $11.1-11.0$ & $15.7-16.1$ & $22.0+6.2$ & $760+130$ & Nurmisr \\
\hline 13 & 16 & Tesfa ym. 1999 & 2 & $128-157$ & $8.8-9.0$ & $16.2-16.3$ & $28.1+2.0$ & $830+50$ & Nurmisr \\
\hline 13 & 17 & Tesfa ym. 1999 & 2 & $132-166$ & $6.9-7.3$ & $15.9-17.6$ & $28.7+0.9$ & $870+0$ & Nurmisr \\
\hline 14 & 18 & Tesfa ym. 2001 & 2 & $156-188$ & $8.8-8.9$ & $20.9-20.4$ & $40.3+0.8$ & $1320+31$ & Nurmisr \\
\hline 14 & 19 & Tesfa ym. 2001 & 2 & $160-193$ & $7.9-8.3$ & $15.9-17.0$ & $29.7-2.0$ & $1023-62$ & Nurmisr \\
\hline
\end{tabular}

${ }^{\mathrm{T}}$ Kontrollin maito- tai valkuaistuotos \pm suurin positiivinen tai negatiivinen vaste 